\title{
Staring Out the Window: A Brief Reflection on my Friend and Mentor, Ben Agger
}

\author{
Joshua E. Olsberg
}

My initial encounter with Ben Agger was shortly before class began on the first day of the semester-he caught me staring out the window, and he called me out by name in order to make his introduction. It was my first semester as a graduate student at the University of Texas at Arlington, and I took a course from Ben entitled "Writing the Social Text." The conversation that followed our introduction at the window was a preview of things to come-Ben was a wave of intellectual energy, and even facing him squarely and listening intently I found myself overwhelmed by the force behind his words and thoughts. I have no doubt those who knew Ben well experienced that sensation during conversations with him just as I did.

I had only a very little sense in that first encounter of how significant both the course I was taking and the man teaching it would be in my intellectual development. During the course I struggled to understand how to write mindfully, creatively, and rigorously_not much was clicking for me, even though I fancied myself a decent creative writer. It was when I began to read Fast Capitalism that I came to understand why writing a social text that adequately distanced itself from the object it sought to critique was so difficult to accomplish. Ben's work spoke to me- - the problem was much larger than my abilities as a writer. It was not that I was simply struggling to constitute the words and ideas in a meaningful way to accomplish the small goals of a given term paper; it was that words and ideas were struggling to exist outside of the normative order imposed by our contemporary iteration of Capitalism. Books were struggling to exist as anything more than that which reproduced the acceptable spectrum of agreement or disagreement within the purview of the system. Critical political perspectives such as Marxism, feminism, etc. were struggling to exist as more than the trappings of identity. Public intellectualism was struggling to exist as anything more than a profession bound within and by neoliberal institutions. Of course not much has changed since my initial reading, even if I have.

It was during that course and that first reading, when I first realized the scope of the problem and the political project it implied should follow, that I experienced a profound sense of frustration. I thought then: "If ideas and texts cannot extricate themselves (however temporarily) from the social structures they seek to critique, then what chance do we have of fixing the obvious iniquities our scholarly studies reveal?"

I wondered then if being a social scientist was tantamount to practicing a profession of describing, in depth and in slow motion, a train wreck that was as inevitable as entropy. I would have quit at that point if it were not for Ben. Ben was encouraging and insistent, unyielding and unflappable in his convictions that the tide would turn, and that people like us would have a lot to contribute when it did.

Ben sought and took every opportunity to buck disciplinary conventions not because it was a statement of style, but because it was a necessity. Why do we write the way we do? Why do we stand on the sidelines and fail to foresee the impending social upheavals that define our present moment? Much discussion in my discipline as of late is about the need to 'decolonize' knowledge production and quit practicing an unconsciously white (and indeed upper-middle class and masculine) Sociology. The consequences of not doing so are to risk descending further into irrelevance and to lack the ability to adequately understand the crucial anti-racist, anti-capitalist movements so visible today. Ben 
was never at risk of that-he remained both a productive scholar and a true public intellectual and was able to do so specifically because he understood the risk of losing the latter in pursuit of the former. He knew the pressure on scholars to 'publish or perish' was a means of constraining intellectual labor and guaranteeing that it occur in such a way that writing books and essays would be reduced to work-for-pay and just that. He pointed out to us that dissent in texts acceptable as long as texts themselves remained ephemeral—this is the era my generation of scholars has come of age in, and if it weren't for Ben Agger, for Fast Capitalism, I'm not sure we would have a critical vocabulary available to us that adequately delineates our situation.

Fast Capitalism was a remarkable accomplishment because it simultaneously articulated why books and ideas were at risk of becoming completely irrelevant as a means of producing social critique, and modeled how they could become relevant in a new way at a time when the social conditions necessitated they do so. It was nothing short of transcendent, and the scope of its contribution is still decades away from being fully understood. For his part, Ben understood passion and resoluteness were mandatory in resisting the conservativizing tendencies that ceaselessly pursue those who try to write and think critically. In an era in which public intellectuals may be feeling trapped or discouraged about the possibilities for emancipatory action, Ben gave us a roadmap to resistance. In many ways that I believe will become more obvious to all of us as time passes, Ben Agger's ideas have contributed to eventually resolving the problems through which we collectively struggle now.

I think Ben approached me that first day because I was staring out the window. He appreciated students that were daydreamers and felt more comfortable writing poetry than literature reviews. When I recall his memory and the impact he made upon me as a teacher, I am struck by the easiness in the way he conducted himself before his students. Showing up to class drenched in sweat, setting down his tennis racket, delivering a flawless and hermetically sealed lecture on Marcuse with a smile on his face, and walking back to the court when the seminar was complete. Ben was brilliant and yet spoke plainly - traits I try hard to emulate. When my father passed away unexpectedly Ben and I had coffee. I remember he made no attempts to be philosophical about the matter, he simply put his hand on my shoulder and said, "I'm sorry Josh." That moment of human contact was profound, and Ben was wise enough to understand that not everything required the kind of exegesis he sought to provide in his work. Still, he never failed to pass along a pearl of wisdom when it was warranted. The last conversation we had via text was vintage Ben, and I sometimes read back through it on my phone. He congratulated me for completing my PhD and landing an academic job and he ended our conversation thusly: "It was all worth it. Out of struggle emerges resolution." 